\title{
The Strategy of Padang City Politicians Win 2014 Election
}

\author{
Sumartono $^{1}$ \\ ${ }^{1}$ Communication Science Ekasakti University at Padang \\ Corresponding Author's Email: rajoameh1999@yahoo.com
}

\begin{abstract}
General elections as a means of democracy that aims to elect the legislator to be an interesting study. One of the interesting things to study is how a politician makes a strategy to win general elections. Because mistakes in strategies to win general elections can have a negative impact on the results. In general, the defeat experienced by a politician who failed to become a legislative member was due to an error in winning the election. In connection with the 2014 general election, the thing that became a general discussion was how a politician was able to combine the strategy of network strength with the use of social media. This study aims to find out how the strategy of politicians of Padang city won the legislative elections so elected to become members of legislator of Padang City 2014-2019 period. This research was done through the paradigm of constructive by phenomenology method. The focus of this research was political communication with the subject of research the members of Padang City Legislator (2014-2019). Number of informants as many as 5 people were selected through purposive s a m pling technique. The informants in this study were obtained by determining the criteria, firstly, member of the Padang City legislator who was recorded as having been a member of the legislator for at least 2 periods. Secondly, having an account and being active on social media for more than 5 years. Data collection techniques were conducted through indepth interviews, observations, and documentation studies. The results show that politicians of Padang City have developed a strategy to win the 2014 legislative election by way of mapping of identity, support area, voting potential, and media utilization. Identity mapping is useful to know whether voters are rational or emotional. This mapping is useful in terms of approaching strategies to win elections. So this can reduce ineffectiveness in campaigning. Support area mapping is useful for knowing the area to be used as vote collecting. While mapping the potential of voters is useful to know the growing political demography. Mapping of potential voters is useful in anticipating the emergence of political mafia who are often present at every election. Utilization of media, especially social media becomes a necessity in getting seats to become legislator. The selection of social media as a communication channel in addition to the policy of the general election commotion limits the campaign through conventional media is also due to the understanding and experience of politicians of Padang City that utilize social media is much cheaper and effective in disseminating to the community compared to using conventional media. There are two suggestions in this study, firstly, every legislative candidate who will compete in the general election should have to map out the strength of his support. This is important so that the use or allocation of
\end{abstract}


funds can be managed properly. Secondly, every legislative candidate must utilize social media optimally. Because, the facts in the field show that in addition to lowcost, social media has a significant influence in influencing society compared to conventional media.

Keywords: strategy, politicians, general election, legislator, social media utilization

\section{INTRODUCTION}

Election in Indonesia is the process of selecting people to fill certain political positions. These positions are diverse, ranging from the President, Members of the Local Legislator, Provincial Legislator, House of Refresentative, to Members of the Regional Representative Council (DPD). Conditionally, general elections are also an attempt to persuade constituents by carrying out campaign activities or socialization to the public. This understanding illustrates that the general election is actually a place to prove that politicians prove themselves whether the strategy that has been done is successful or not.

Strategy is a goal to ensure that the political communication process in persuading constituents can run well and produce maximum effects (Wahid, 2016: 187). Austin and Pinkleton (2001: 11) explain how to start a strategy. According to him, the strategy starts to formulate the goals. What is the purpose to be achieved. Politics aims to achieved the people's trust.

The strategy of influencing constituents in elections is an interesting discussion because elections become a fighting arena for the candidates' strategies or politicians to win the votes of constituents. Communication strategies carried out by politicians contextually involve procedures and activities that are generally in the world of business and commerce. That is, this shows that the process of elections is increasingly open in the political system in Indonesia. In this regard Asep S Muhtadi stated that at least the current political reality faces three consequences. First, there is a political shift in the room to outdoor politics. In the past, to elect a president, governor, mayor / regent, it was enough to do it in a narrow space called the parliament building. But now, the hustle and bustle moves to a more open public area because it involves all the people.

Second, the development of electorates, namely voters as determinants. To convince the public as a winner, candidates must persuade them in various ways. Third, changes in the style of relations between political parties, politicians, party members, and voters. Since the 2009 election with the most voting system, friction not only occurred between parties, but also with fellow one-party cadres. Likewise at the grassroots level, the community is not only fragmented in certain political parties and ideologies, but more scattered at narrower points because the friction can occur in every legislative candidate (Tabroni, 2012: 125).

The process of winning political competition in the electoral arena can be declared as a battle in the marketing world. As is known in marketing known as Marketing Mix (4P): Product, Price, Place and Promotion. In a political context, what is meant by products are candidates who compete with each other. These 
candidates are assumed to be products. The most important aspect of marketing is about promotion. The essence of the promotion is how to convey a message about product quality, price and quality and other characteristics that distinguish it from other products. In the perspective of political marketing, the political world is seen as an activity that relates to beliefs, principles, idealism and debate about how all these activities are carried out properly including winning general elections and obtaining the allocation of power as desired (Lees and Marshment, 2009: 5) .

The focus of this study is aimed at Padang City politicians. The election of Padang City politicians as the subject of the study was caused by: First, the reality that since the reform era general election was held there were no election participants in the City of Padang that dominated. 4 general elections (1999, 2004, 2009, and 2014) recorded 4 political parties that received the most votes (PAN Party or National Mandate Party won the most votes in the 1999 legislative elections; 2004 PKS or Prosperous justice party won the most votes; then in 2009 the Democratic Party won the most legislative seats and for the 2014 legislative elections the Gerindra party triumphed in the city of Padang and at the same time made its cadres occupy positions as Chairmen of the Padang City DPRD 20142019). This shows the dynamics of political life in the city of Padang is so massive. While in other areas, such as Bandung City, Yogyakarta City, Surabaya City, Semarang City, Makassar City, Medan City, Palembang City, Pekanbaru City, Pontianak City, and Banjarmasin City the dominance of certain political parties has emerged. In the cities of Bandung, Surabaya, and Medan PDI-P won legislative elections twice (1999 and 2014). In the cities of Semarang and Yogyakarta the PDIP dominated the results of the legislative elections from 1999 to the 2014 elections. While the cities of Makassar, Banjarmasin City, and Pontianak, the Golkar Party dominated the legislative election results.

Secondly, the results of the 2014 general election as reported by the Padang City Election Commission on its official website (www.kpu-kotapadang.go.id) stated that the Gerindra Party obtained the most votes of 44,538 (6 seats). While in the Padang City regional election held on March 5, 2014, the Mahyeldi-Emzalmi pair supported by the Prosperous Justice Party won the most votes. Referring to the reality that is where the Mayor of Padang was elected and also the Governor of West Sumatra who is a cadre of the Prosperous Justice Party (PKS), it should be based on political calculations of course PKS won or won the most votes in the general election. But the facts on the field of the Gerindra Party which won the most votes. This shows that the role of politicians in the city of Padang is quite significant in influencing the political behavior of the people of Padang City.

Third, Law No. 12 of 2012 concerning the Election of the DPR, DPRD and DPD which limits the implementation of campaigns including in the mass media (print and electronic) as a major effort in reducing the high or expensive costs of campaigning in Indonesia, considering that in the previous two elections, political parties were complicated by high campaign costs, so that only parties that have a lot of capital are able to show their faces in public through mass media facilities, while small parties experience difficulties (Muhtadi, 2013: 78) become a breath of 
fresh air for politicians to use social media as a channel for political communication. This fact is reinforced by the results of interviews of researchers with Anita Mawaddah (Advertising Manager TVRI Sumbar) who said that there was a decrease in the cost of political advertising costs from politicians by $35 \%$ from 358 million in the 2009 election to 125 million in the 2014 election. West Sumatra People's Daily General Manager) who pointed out that since council members began to use social media the advertising expenditure for print media (Rakyat Sumbar) decreased by $15 \%$.

\section{LITERATURE REVIEW}

The theory used in this study is the Social Exchange Theory and Dramaturgi Theory Erving Goffman. According to Thibaut and Kelley (in Komala, 2009: 172173), the four main concepts of Social Exchange Theory are: rewards, costs, profits and the level of comparison.

1. Reward is any consequence that is valued (+) obtained by a person in a relationship. Rewards in the form of money, social acceptance, or support for the values held by him. The value of a reward varies from person to person, and differs from one time to another.

2. Costs are the result of being assessed (-) that occurs in a relationship. Costs can be in the form of time, effort, conflict, anxiety and collapse of self-esteem. The cost also changes from time to time.

3. Profit or yield is a reward minus costs. When an individual feels in an interpersonal relationship that he is not making a profit at all, he will look for other relationships that bring profit.

4. The level of comparison shows the standard size used as a criterion in assessing individual relationships. At this time the standard size can be in the form of individual experiences in the past or other alternative relationships that are open to him.

Each individual establishes friendship, of course, has the goal of caring for each other. These individuals must be expected to do something for others, help each other if needed, and give each other support when sad. However, maintaining a friendship relationship also requires certain costs, such as lost time and energy and other activities that are not implemented. Although these costs are not seen as something that is expensive or burden some when viewed from the point of view of the rewards obtained from the friendship. however, these costs must be considered if we objectively analyze the transaction relationships that exist in friendship. If the costs incurred do not appear to be in accordance with the rewards, what happens is actually an unpleasant feeling on the part of those who feel that the benefits received are too low compared to the costs or sacrifices that have been given.

According to Michael Roloff (2010: 251) social exchange theory has various implications for understanding aspects of interaction, including the following:

1. Interaction can be seen as a symbolic exchange of resources.

2. Interaction means the negotiation of various exchange resources 
3. Interactions contain meaning where each individual creates exchange relationships and networks.

4. Interactions contain meaning where each individual manages and improves exchange and network relationships.

The principle of social exchange theory is a general description of the elements of this theory, namely an analysis, motives, advantages, and social agreements (Wirawan, 2014: 174).

\section{Analysis Unit}

The unit of analysis in social order is something that is observed in research and plays an important role in explaining social order and individuals. This theory even though it does not start from asking, intuition, or public opinion, but ultimately will bring up matters related to their institutions, groups, and sentiments. Social exchange theory is also not only centered on individuals, but rather on order and change (Wirawan, 2014: 175).

2. Exchange Motives

The motive in social exchange theory assumes that everyone has their own desires. Each person will need something, but something that is not a common goal. Thus, this theory assumes that people make exchanges because they are motivated by a combination of various unique goals and desires. Exchange theory views motivation as personal and individual. However, motivation will later refer to culture and personality. Motivation refers to when getting the desired item, pleasure, satisfaction, and other things that are emotional. For example, donors who give goods or a sum of money and help the lives of people who are immersed in water, such actions can be explained according to the theory of social exchange that is to gain emotional satisfaction (Wirawan, 2014: 175).

2. Benefits or Benefits

Even the most selfish person is not in the void of life, because he gives something to others and gets pleasure from his emotions. Costs incurred by someone or obtain a "gift" (reward), sometimes do not take into account the costs incurred. Therefore, a "cost" can be defined as an effort needed to obtain a satisfaction, plus a potential reward that will be obtained when doing something. A person's satisfaction or reward can be considered as an advantage (Wirawan, 2014: 175).

3. Social Endorsement

Social endorsement is a satisfaction and is a common motivator in the exchange system. The amount of meaning of rewards is not easy to be given a limit, because it is indivual and emotional in accordance with the diversity of people. However, according to the exchange theory, reward is a reward that has the power of social approval. In everyday life, everything that is loved will be sought in their social relations. People will be more like or match with others who legitimize themselves (Wirawan, 2014: 176).

The basic assumptions of social exchange theory come from human nature and the nature of relationships. The assumptions made by the theory of social exchange regarding human nature are as follows: 
1. Humans achieve appreciation and avoid punishment.

The thought that humans seek rewards and avoid punishment in accordance with the conceptualization of the reduction of encouragement. This approach holds that people's behavior is motivated by an internal push mechanism. When people feel this urge, they are motivated to reduce it, and the process of implementing it is fun.

2. Humans are rational beings.

That humans are rational beings is an important assumption for social exchange theory.

3. Standards used by humans to evaluate sacrifices and rewards vary over time and from one person to another.

Third, these assumptions indicate that this theory must consider the existence of diversity. There is no single standard that can be used by everyone to determine what sacrifice and appreciation is. Assumptions made by social exchange theory about the nature of a relationship :

1. Relationships are interdependent

In a relationship when a participant takes an action, both one participant and their overall relationship will be affected.

2. Life related is a process

The importance of time and change in the life of a relationship. In particular time affects exchange because past experiences lead to judgments about rewards and sacrifices, and this judgment influences subsequent exchanges.

Furthermore, this study uses the Dramaturgy Theory of Erving Goffman. The Goffman dramaturgy approach corroborates the view that when humans interact with their companions, they want to manage the messages that they expect to grow in others towards them. For this reason, everyone performs for others. Dramaturgists view humans as actors on a metaphorical stage who are playing their roles.

The concept used by Goffman comes from Burke's ideas, thus the dramaturgy approach as one of the variants of symbolic interactionism that often uses the concept of "social role" in analyzing social interactions, which are borrowed from the theater repertoire. Role is a socially defined expectation that someone plays in a situation to give a certain image to the audience present. How the actor behaves depends on his social role in certain situations. The focus of dramaturgy is not the self-concept that the actor brings from the situation to another situation or the total number of individual experiences, but the socially situated self that develops and regulates specific interactions. According to Goffman, self is "a result of collaboration" (collaborative manufacture) that must be produced new in every event of social interaction.

Goffman assumes that when people interact, they want to present a selfimage that others will receive. He called the effort "impression management", the techniques used by actors to cultivate certain impressions in certain situations to achieve certain goals. In the dramaturgic perspective, life is like a theater, social 
interaction that is similar to the show above the fan, which displays the roles played by actors. To play this role, usually the actor uses verbal language and displays certain noverbal behaviors and wears certain attributes, such as vehicles, clothing and other accessories that fit his role in certain situations. The actor must focus his mind so that he does not sprain the tongue, maintain self-control, make gestures, maintain the tone of voice and express the face that suits the situation.

According to Goffman, social life can be divided into "front region" (front region) and "back region" (back region). The front region refers to social events which show that individuals are stylish or display their formal roles. They were playing their role on the stage in front of an audience. On the contrary, the back area refers to places and events that enable it to prepare its role in the front region. The front area is like the front stage, which is watched by the audience, while the back area is like a back stage or a dressing room where the performer relaxes, prepares, or practices to play his role on the front stage.

Goffman divides the front stage into two parts: personal fronts and personal front settings consisting of tools that are considered by the public as equipment that actors carry into settings, for example doctors are expected to wear a doctor's coat with a stethoscope hanging from his neck. Personal fronts include verbal language and the body language of the actor. For example, polite speech, pronunciation of foreign terms, intonation, posture, facial expressions, clothing, age appearance and so on. To some degree, all aspects can be controlled by actors. Relatively fixed traits such as physical traits, including race and age are usually difficult to hide or change, but actors often manipulate them by emphasizing or softening them, for example blackening back gray hair with hair dye. While the setting is a physical situation that must exist when the actor performs, for example a surgeon requires an operating room, a taxi driver needs a vehicle. (Mulyana, 2013: 115)

The focus of Goffman's attention was actually not only individuals, but also groups or what he called the team. In addition to carrying out roles and characters individually, social actors also try to manage the impressions of others on their groups, be they families, workplaces, political parties, or other organizations they represent. All of the members by Goffman were called "performance teams" (performance teams) that dramatized an activity. Team collaboration is often carried out by members in creating and maintaining appearances in the front region. They must prepare the show equipment carefully and run the show, play a decent core player, perform the show as carefully and efficiently as possible, and if necessary also choose the appropriate audience. Each member supports each other and if necessary gives direction through nonverbal cues, such as hand signals or eye signals, so the performance runs smoothly. (Mulyana, 2004: 123).

\section{METHODOLOGY}

The method used in this study is phenomenology. The reason the researchers used phenomenological research methods was because first, the data used were in the form of words or not in the form of numbers where the researcher tried to express the informant's experience as it is. This is in accordance with the 
phenomenological research method proposed by Giorgi (Raco, 2012: 156) that in the phenomenology method the researcher gives meaning from the experience of the informant giving the meaning of his experience.

Second, this study aims to understand the meaning of the experience experienced by members of the Padang City Legislator 2014-2019 in using social media. Dahlberg (in Raco, 2011: 55) writes that being in the world is always related to giving meaning. Whatever we make, and think has a relationship with the meaning or meaning in our mind. There is no action and thought that is not related to meaning. The meaning and meaning of this is what actually makes people live, act, and act. Thus, the meaning or meaning is unavoidable from this life. In essence qualitative research uses a phenomenological approach. This means that researchers go to the field by observing the phenomena that occur in the field naturally. But later that will distinguish each type of research is the focus of research. Does the research focus on culture, phenomena, cases, and so on.

This study uses phenomenological studies or methodologies. According to Stephen W. Littlejohn (2005: 336), phenomenology is an approach that assumes that a phenomenon is not a stand-alone reality. Phenomena that appear are objects that are full of transcendental meanings. The daily social world in which humans live is always an intersubjective and full of meaning. With thus, the phenomenon understood by humans is a reflection of transcendental experience and understanding of meaning. From this explanation, it can be mentioned that several key words in phenomenology are objects, meanings, experiences, and awareness of individuals. All of these things play an important role in phenomenological studies. So this study seeks to study experiences from the perspective of Padang City DPRD members from 2014 to 2019 in using or utilizing social media.

This research uses phenomenology method because it is as Edmund Husserl's statement (Kuswarno, 2009: 10) that "with phenomenology we can learn forms of experience from the point of view of people who experience it directly, as if we experience it ourselves. Phenomenology not only classifies every conscious action taken, but also includes predictions of future actions, seen from the aspects associated with them. Everything is sourced from how someone interpreted the object in his experience. Therefore, it is not wrong if phenomenology is also interpreted as a study of meaning, where the meaning is broader than just the language that represents it. "

\section{RESEARCH RESULTS AND DISCUSSION}

Strategy is the overall approach that is related to the implementation of ideas, planning, and execution of an activity in a certain period of time. In a good strategy there is coordination of the work team, having a theme, identifying supporting factors that are in accordance with the principles of implementing ideas rationally, efficient in funding, and having tactics to achieve goals effectively. The success of winning the legislative elections cannot be separated from the strategy implemented. This strategy includes planning, implementation, monitoring and 
evaluation so that efforts to pass on persuasion to the voting community must continue to be carried out, which in turn provides support for their vote to vote.

\section{Strategy of Ground Attacks and Air Attacks}

Usman Ismail (Informant / Member of Padang City DPRD 2014-2019) stated that there are two ways a DPRD member can do to maintain a position as a member of the DPRD, namely through ground attacks and air attacks. Ground attacks are carried out by "door to door". While air strikes are carried out by utilizing social media.

Usman assessed that the strategy of winning the 2014 election through social media helped him a lot in communicating himself to the public. Besides being more effective, according to Usman the strategy through social media is much cheaper than doing strategy through conventional media.

Read more Usman Ismal said:

"There are two ways that I can maintain my position as a member of the Padang City DPRD, namely through land attacks and air strikes. Ground attack by "door to door". I do air strikes by utilizing social media. In every meeting with the community, I only emphasize that the best way for a region to be considered by the government is that there must be a representative sitting in the legislature. Besides that I also formed a support community that was entirely women. Because in my opinion women or mothers are more loyal than men. During the 2014 election I had almost 300 members (successful teams). Well, they are the ones who move to promote me. Usually after finishing the election I help the community of these mothers go refreshing to tourist areas in West Sumatra. All of my costs are tangible. The limitation of the use of conventional media issued through KPU regulations when the campaign was very profitable for me, because far before the 2009 election I had used social media especially Facebook so that during the 2014 full election I used social media. Frankly the 2014 election costs are far cheaper than the 2009 elections. I think this is because of social media."

The strategy of ground attacks and air strikes was also carried out by Budiman (Politician of the Prosperous Justice Party) in winning the 2014 election. Budiman argued that the strategy of combining friendship with the community and the use of social media became the key words in winning the general election. Read more about how:

"My strategy is simple, namely how we can build uninterrupted communication with the community and community leaders. Building communication is intense and continuous. Next, what I do is by increasing the informal recess. By utilizing our social media as if you have an unlimited recess period. In addition, what is equally important is how we are able to accommodate the aspirations of the people and be able to channel them appropriately and quickly. My background from IAIN allows me to easily meet the community to socialize myself. Besides I often give lectures in majelis taklim, every Friday I am also a preacher in the Padang City mosque."

Maidestal Mahesa Day which was recorded to have been a member of the Padang City DPRD 3 times (2004-2009; 2009-2014; 2014-20190) stated that the 
ground attack strategy became a significant medium in delivering it to become a member of the Padang City DPRD. Maidestal stated that the taklim assemblies and posyandu were the two chosen activity agendas to socialize themselves to the community and provide maximum results in reaping votes in the last three elections.

Read more Maidestal Mahesa Day revealed:

"At the age of 23 years I was a member of the board. My struggle in the 2004 elections was heavy, because I was young and didn't know much about politics. Luckily I have a parent mentor (father) who is also a politician. Besides that, the background of social political education helped me a lot in understanding the political map in the electoral district (electoral district). The condition of the people of Padang City based on the traditional basandi syarak, syarak basandi of the Kitabullah provides an understanding to me that an approach from the religious side can be used as a provision to approach the community. Besides that, I see mothers often gather at the posyandu.

Therefore I decided that the socialization would be carried out through the taklim assembly and strengthening the posyandu. I strengthened the voting base a lot among mothers in the majlis taklim and posyandu. For 2 years, exactly in 2002, I made a network through the taklim assembly. I am the data of any famous buya or ulama in the city of Padang. Then I coordinated with the majlis taklim mothers in my electoral district (dapil). My electoral district includes North Padang Subdistrict, West Padang Subdistrict, and Nanggalo Sub-District. My mass base concentration in North Padang. There are around 15 Majelis Taklim that I have built. Likewise with the Posyandu, I collaborated with Posyandu cadres. Sometimes I attend the posyandu to stay in touch with the mothers. Every now and then I have a healthy baby race. It turns out that this method works to get me to become a member of the board. In the 2004 election I got almost 2,800 votes. "

\section{Strategy of Mesh Net}

A strategy that was slightly unique in winning the 2014 general election was stated by Zaharman (Hanura Party Politician) who implemented a strategy of mesh net or insect repellent. The strategy of mesh net or mosquito repellent strategy is a strategy to influence the political choices of the community starting from their own families to the general community in the electoral district. In detail, Zaharman explained:

"The strategy that I implemented was the strategy of mesh net or insect repellent. I and the wife of a native Kuranji citizen. Well, according to the theory of mesh net or insect repellent, then the strategy I started from the nuclear family (my family and wife's family), relatives of one village, then neighbors near the house, then the villagers. After the strategy to search for sounds I do it through the network that I have. I am active as a mosque administrator, Youth Group Bulider, and the chairman of the Kuranji village. Everything I have mapped so that I can determine the basis of my voice. After mapping and knowing where our base area is, then I set up a stabilization action. Apart from the network that I have, I also use the network that my wife has. My wife is the principal at Islamic school. In each meeting I first did what I heard a lot from the public. I noted various complaints 
and input from the community for the next time I found the solution. The most important thing is often to meet the community, discuss, exchange ideas, and establish friendships with community members. There are two ways that I do, first, official. I do this through recesses, field visiting, and community invitations (such as the youth event, or recitations in mosques). Second, informal ways. I do this through visiting sick people, fulfilling marriage invitations, or thanksgiving."

\section{Strategy of Areas Mapping}

Muzni Zen (Padang City politician from the Gerindra Party) carried out a strategy to win the 2014 election by areas mapping that could be used as voice barns. Mapping this area is important in the midst of the 5-year political competition. Read more Muzni Zen states:

"Come to think of it, I am not a native of Padang, because I come from Pariaman. I migrated to Padang. In carrying out the strategy, of course I first mapped out which areas could be used as a barn for sound. Sound barns are usually near where we live. Based on my experience, I observed that in my constituency (especially Kuranji) there was a lot of housing. If the housing is not so complicated, it is enough we coordinate with who is the leader or the person who is elder. We negotiate when we can meet with the community. When it's determined, it's time we come and we provide consumption for the people who come. It's different if we want to socialize or stay in touch with indigenous people. We report to the local RT or Lurah and then we discuss and ask the mothers for the event. My experience for their indigenous people is to cook so that I only prepare what they need. My observations are easier for mothers to influence, if they say they support usually do not betray. But if the gentlemen deviated a lot. Moreover, the young man, he can't hold his words. I learned about dealing with youth. In the 2004 elections a lot of my funds helped the youth but when the election was over my vote was not as expected. Because of the 2009 and 2014 elections I was reluctant to deal with youth. One more strategy I won was by carrying out the dawn attack. The dawn attack here is not money politics or money sharing. But the dawn attack I was referring to was the day before the voting I was helped by the team to divide the paper leaflets on how to vote well. Why do I do this, my understanding of the legislative candidates is that of course all of that causes confusion for the people. Now, by carrying out the dawn attack, the people who receive our leaflets will remember and will vote for us. "

\section{CONCLUSION}

Discussions about the strategy of politicians in winning general elections are always interesting to study. The good strategies will create the positive results for politicians to win elections. Based on the results of the study revealed that there are three strategies of Padang City politicians in winning legislative elections. First, the strategy of the lawa net or insect repellent. The lawa net strategy or the mosquito repellent strategy is a strategy to influence the political choices of the community starting from the family itself, strategy for generai public, and strategy for the constituency. The strategy begins by providing understanding and asking for 
support from one's own family (nuclear family), relatives, or close relatives. Furthermore, requesting support through the network owned.

The second strategy is carried out through the mapping of areas that are used as a granary. Mapping of the region becomes important in general election competition. Legislative elections require funds both for socialization, campaigning and procuring props. Mapping the area is very helpful in allocating funds so that it is known how much funding is needed early.

The third strategy is the use or use of media or the term to carry out ground attacks and air strikes. Ground attacks are carried out by way of "door to door" or meeting with constituents. While the air strikes were carried out using social media. For politicians, the strategy of winning the 2014 election through social media helps a lot in communicating itself to the public. Besides being more effective, according to Padang City politicians a strategy through social media is cheaper than doing strategy through conventional media.

\section{REFERENCES}

Austin, Erica Weinstraub, and Pinkleton, Bruce E, 2001. Strategic Public Relations Management, NewJersey : Lawrence Erlbaum Associate.

Creswell, John W. 2014. Penelitian Kualitatif \& Desain Riset, Yogyakarta : Pustaka Pelajar.

Jenifers Lees and Marshment, 2009. Political Marketing Principles and Applications, London: Routledge.

Komala, Lukiati. 2009. Ilmu Komunikasi: Perspektif, Proses dan Konteks. Bandung: Widya Padjajaran.

Kuswarno, Engkus. 2009. Fenomenologi : Fenomena Pengemis Kota Bandung, Bandung : Widya Padjadjaran.

Littlejohn, Stephen W, Karen A Foss, 2014. Teori Komunikasi, Jakarta : Salemba Humanika.

Muhtadi, Buhanuddin, 2013. Perang Bintang 2014, Jakarta : Noura Book.

Mulyana, Deddy, 2013. Metodologi Penelitian Kualitatif, Bandung : Remaja Rosdakarya.

Raco, Jozef R. 2012. Metode Fenomenologi Aplikasi pada Entrepreneurship, Jakarta: Grasindo.

Roloff, Micheal. 2010. Teori Sosilogi Klasik dan Modern, Jakarta: PT. Gramedia Pustaka.

Tabroni, Roni, 2012. Komunikasi Politik pada Era Multimedia, Bandung : Simbiosa Rekatama Media,

Wahid, Humaimah, 2016. Komunikasi Politik,Teori, Konsep,dan Aplikasi pada Era Media Baru, Bandung : Simbiosa Rekatama Media.

Wirawan, I. B., 2014. Teori-Teori Sosial dalam Tiga Paradigma, Jakarta : Prenadamedia Group. 